\title{
Paul Pascon 1932-1985
}

\section{Claude Lefébure, Geneviève Bédoucha, Robert Cresswell et Martine Cresswell}

\section{OpenEdition}

Journals

Édition électronique

URL : https://journals.openedition.org/tc/944

DOI : $10.4000 /$ tc. 944

ISSN : 1952-420X

Éditeur

Éditions de l'EHESS

Édition imprimée

Date de publication : 1 février 1986

ISSN : 0248-6016

Référence électronique

Claude Lefébure, Geneviève Bédoucha, Robert Cresswell et Martine Cresswell, « Paul Pascon

1932-1985», Techniques \& Culture [En ligne], 6 | 1986, mis en ligne le 24 janvier 2006, consulté le 29 septembre 2022. URL : http://journals.openedition.org/tc/944 ; DOI : https://doi.org/10.4000/tc.944

Ce document a été généré automatiquement le 29 septembre 2022.

Tous droits réservés 


\section{Paul Pascon 1932-1985}

Claude Lefébure, Geneviève Bédoucha, Robert Cresswell et Martine Cresswell 